\title{
Pharmacotherapy and psychotherapy for bipolar disorder in the context of early childhood trauma
}

\author{
Farmakoterapia i psychoterapia choroby afektywnej dwubiegunowej \\ w kontekście traumy wczesnodziecięcej
}

Paulina Jaworska-Andryszewska, Janusz Rybakowski

\section{ABSTRACT}

The current pathogenic paradigm of mood disorders proposes a model of gene-environment interaction, linking genetic predisposition, epigenetic regulation

\begin{tabular}{|c|c|c|}
\hline 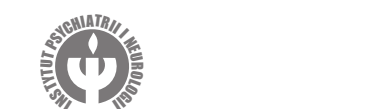 & $\begin{array}{l}\text { Received } \\
\text { Accepted }\end{array}$ & $\begin{array}{l}28.01 .2019 \\
29.03 .2019\end{array}$ \\
\hline \multicolumn{3}{|c|}{ AFFILIATION / AFILIACJA } \\
\hline \multicolumn{3}{|c|}{$\begin{array}{l}\text { Klinika Psychiatrii Dorosłych, Uniwersytet Medyczny } \\
\text { w Poznaniu }\end{array}$} \\
\hline $\begin{array}{l}\text { KEYWORDS } \\
\text { - } \text { psychotherapy } \\
\text { - bipolar affective } \\
\text { disorder } \\
\text { - pharmacotherapy } \\
\text { - childhood trauma } \\
\text { - Cognitive Behavioural } \\
\text { Therapy } \\
\text { - schema therapy }\end{array}$ & $\begin{array}{l}\text { SŁowA } \\
\text { - choroba } \\
\text { dwubieg } \\
\text { - psychote } \\
\text { - farmakot } \\
\text { - psychote } \\
\text { wczo-bel } \\
\text { - trauma } \\
\text { - terapia s }\end{array}$ & $\begin{array}{l}\text { CzOWE } \\
\text { tywna } \\
\text { wa } \\
\text { ia } \\
\text { pia } \\
\text { ia pozna- } \\
\text { ioralna } \\
\text { cięca } \\
\text { matów }\end{array}$ \\
\hline \multicolumn{3}{|c|}{ CORRESPONDENCE ADDRESS / ADRES DO KORESPONDENCJI } \\
\hline $\begin{array}{l}\text { Paulina Jaworska-Andrysz } \\
\text { Klinika Psychiatrii Dorosł } \\
\text { ul. Szpitalna } 27 / 33,60-572 \\
\text { email: pjaworska.andrysze }\end{array}$ & $\begin{array}{l}\text { ka } \\
\text { JM w Poznan } \\
\text { nań, Poland } \\
\text { a@gmail.com }\end{array}$ & \\
\hline
\end{tabular}

and effects of the environment. Among multiple environmental factors, the experience of childhood trauma can be connected with the pathogenesis and course of bipolar disorder (BD) as well as play a role in its pharmacological and psychotherapeutic treatment. Genetic predisposition and epigenetic factors are significant factors that shape the mechanisms of the influence of childhood trauma on the occurrence and course of BD in adulthood. By examining the influence of a number of genes on genetic predisposition, evidence was obtained that the most important genes in this respect are the serotonin transporter gene and the FKBP5 gene. Neurobiological effects can also involve epigenetic mechanisms such as DNA methylation, which can exert an effect on brain function over long-term periods. Moreover, the paper discusses the significance of early childhood trauma in therapeutic management of bipolar disorder. Negative childhood experiences can be connected with difficulties in pharmacological treatment, such as resistance to treatment with antidepressants and mood-stabilisers. Psychotherapeutic methods that directly or indirectly address early childhood trauma play an important role in the treatment of patients suffering from bipolar disorder, who have experienced such events. Among these methods, the most promising data were obtained for psychoeducation and cognitive-behavioural therapy. It appears that psychotherapy should be considered in every patient with the experience of early childhood trauma. 
Psychotherapeutic management combined with pharmacotherapy significantly improves the results of pharmacological treatment.

\section{STRESZCZENIE}

Obecny paradygmat patogenezy chorób afektywnych proponuje model interakcji gen-środowisko, łączący predyspozycję genetyczną, regulację epigenetyczną i wpływy środowiskowe. Wśród licznych czynników środowiskowych doświadczenie traumy wczesnodziecięcej może być związane z patogenezą i przebiegiem choroby afektywnej dwubiegunowej (CHAD) oraz odgrywać rolę w jej leczeniu zarówno farmakologicznym, jak i psychoterapeutycznym. W mechanizmach wpływu negatywnych wydarzeń w okresie dzieciństwa na pojawienie się i obraz CHAD w wieku dorosłym istotne są predyspozycja genetyczna i czynniki epigenetyczne. Uzyskano dowody, że na predyspozycję genetyczną wpływa szereg genów, z których najważniejszy to gen transportera serotoniny i gen FKBP5. Efekty neurobiologiczne traumy mogą też obejmować mechanizmy epigenetyczne, takie jak metylacja DNA, co może mieć wpływ na funkcjonowanie mózgu w ciągu całego życia. W artykule omówiono również znaczenie występowania traumy wczesnodziecięcej dla postępowania terapeutycznego w CHAD. Negatywne wydarzenia okresu dzieciństwa mogą się wiązać z trudnościami w leczeniu farmakologicznym, takimi jak np. występowanie lekooporności w odniesieniu do leków przeciwdepresyjnych i normotymicznych. Istotne miejsce w leczeniu osób z CHAD, które przebyły traumę wczesnodziecięcą, mają metody psychoterapeutyczne, które w sposób bezpośredni lub pośredni odnoszą się do tych wydarzeń. Wśród tych metod najwięcej obiecujących danych zgromadzono w odniesieniu do psychoedukacji oraz psychoterapii poznawczo-behawioralnej. Wydaje się, że o psychoterapii należy myśleć w każdym przypadku osób z traumą wczesnodziecięcą. Postępowanie psychoterapeutyczne stosowane łącznie $\mathrm{z}$ farmakoterapią $\mathrm{w}$ istotny sposób polepsza wyniki leczenia farmakologicznego.

\section{Introduction}

The current paradigm of pathogenesis of affective disorders puts forward the gene and environment interaction model, which links genetic predisposition, epigenetic regulation and environmental influences (Uher 2014, Rybakowski 2017). Affective disorders are characterised by significant heritability, which is higher in the case of bipolar disorder (85\%) (McGuffin et al. 2003) than in the case of recurrent depressive disorders (37\%) (Sulivan, Neale and Kendler 2000). One of the environmental factors that play an important role in the pathogenesis of bipolar disorder (BD) is life events, especially those that take place during childhood. Studies conducted so far indicate that BD patients are significantly more likely to have experienced various types of early childhood trauma than healthy individuals. Negative life events in childhood are associated with a more severe course of $B D$ and may also be linked to poorer treatment response (deCodt et al. 2016). The influence of early childhood trauma on the occurrence and course of bipolar disorder is associated with genetic predisposition and epigenetic mechanisms.

This paper discusses the influence of early childhood trauma on the occurrence and course of BD, the role of genetic and epigenetic factors in this process and the significance of negative events in childhood for the pharmacological and psychotherapeutic treatment of $\mathrm{BD}$.

\section{Early childhood trauma and the occurrence and course of bipolar disorder}

Traumatic experiences and other negative events in childhood are understood as stressors that cause neurobiological changes in the central nervous system. In modern psychiatry, negative childhood experiences are events described as critical, stressful, traumatic or significant (Kasprzak and Kiejna 2013). These include sexual violence, physical violence, emotional violence, losing one's parents and other experiences that meet the criteria for diagnosing post-traumatic stress disorder. At the same time, not only situations described as trauma, but also, for instance, neglect or excessive discipline in the family of origin can be stressors that may be associated with the development of mental disorders (Read et al. 2005).

Adverse life events, especially during childhood, may significantly increase the risk of BD occurrence. Retrospective studies show that patients who suffer from $B P$ are more likely to have experienced negative events in childhood than healthy people. A study of $206 \mathrm{BD}$ patients and a control group of 94 showed that BD patients were significantly more likely to have experienced complex trauma in childhood (63\%) than the individuals in the control group (33\%) (Etain et al. 2010). This phenomenon has also been described in numerous summaries and meta-analyses (Aas et al. 2016, Aldinger et Schulze 2017, Daruy-Filho et al. 2011, Etain et al. 2008, Fisher et 
Hosang 2010, Jaworska-Andryszewska et Rybakowski 2016, Kasprzak et Kiejna 2013, Palmier-Claus et al. 2016).

A childhood event that may be relevant to BD later in life is the experience of an early loss of a parent or a long-term separation from a parent. It was found that such an event increases the risk of the development of the disease by 2.6 times (Agid et al. 1999). A similar study, which was recently conducted by Paksarian et al. (2015) also found that there is a significant relationship between the experience of separation from a parent and BD.

In a study conducted in our centre, we compared groups of 52 patients with $\mathrm{BD}$ and 52 healthy control subjects, similar in relation to gender and age. We found that in comparison to control subjects, patients with bipolar disorder had experienced more physical, emotional and sexual violence, more emotional and physical neglect and more often experienced parental death, abandonment, divorce and long-term separation (Jaworska-Andryszewska et al. 2016).

Negative childhood experiences may have a significant impact on the clinical course of BD. This applies both to the total number of negative experiences during childhood and to the various forms of violence that influence different aspects of the disease. Experiencing physical violence in childhood was associated with early onset of the disorder, delayed diagnosis and treatment, occurrence of rapid-cycling, psychotic symptoms, suicide attempts, severe manic episodes and an increased number of hospitalisations. Patients who had experienced physical violence were more likely to suffer from post-traumatic stress disorder (PTSD) and abuse psychoactive substances. Sexual abuse in childhood was associated with early onset of the disorder, delayed treatment, occurrence of rapid-cycling, repeated suicide attempts, psychotic symptoms, more severe manic episodes, co-occurrence of PTSD and abuse of psychoactive substances (Daruy-Filho et al. 2011, Aas et al. 2016). In a study by Etain et al. (2013), emotional violence was associated with a younger age of disorder onset, with suicide attempts, occurrence of rapid-cycling, more depressive, manic and hypomanic episodes and cannabis abuse. In another study, the experience of emotional violence was associated with psychoactive substance abuse and rapid cycling (Garno et al. 2005). Moreover, neglect in childhood was linked to a younger age of bipolar disorder onset (Kessing et al. 2004).

In a study of 900 patients with bipolar disorder, Post et al. (2013) showed that early childhood trauma, in particular physical, emotional and sexual violence, was associated with coexisting somatic disorders. Allergies, chronic fatigue syndrome, hypertension, hypotension and head injuries were found to be more common in patients who experienced physical violence. Sexual abuse was associated with irritable bowel syndrome and emotional abuse was linked to arthritis and migraine. A correlation was also found between general early childhood trauma and total number of somatic disorders such as allergies, arthritis, asthma, chronic fatigue syndrome, dysmenorrhoea, fibromyalgia, head injuries, hypertension, hypotension and migraine.

The latest meta-analysis of the relationship between negative experiences in childhood and clinical results in the course of bipolar disorder shows that BD patients who have had negative experiences in childhood are characterised by a younger age of disorder onset, more manic and depressive episodes, increased severity of manic and depressive episodes, increased severity of psychosis, a higher risk of co-occurrence of post-traumatic stress disorder, anxiety disorders, alcohol abuse, increased risk of rapid-cycling course and occurrence of suicide attempts (Agnew-Blais, Danese, 2016).

A Polish study, which included 52 BD patients aged $47+12$ years, showed that negative events in childhood had a significant impact on the development and course of the disorder and were associated with factors such as age at the onset of the first episode of the disorder, age at the moment of diagnosis, presence of psychotic symptoms, occurrence of suicide attempts, rapid-cycling course, treatment-resistance, co-occurrence of other mental disorders (anxiety disorders) and co-occurrence of somatic disorders (hypertension, obesity). Violence and emotional neglect were associated with the highest number of adverse clinical features, such as psychotic symptoms, occurrence of suicide attempts, rapid-cycling course and anxiety disorders. Emotional abuse was associated with a lower risk of hypertension. Sexual abuse was associated with an earlier onset of the disorder and a long-term separation from a parent was linked to the occurrence of anxiety disorders and obesity. The results indicate that emotional violence and neglect are most strongly associated with worse course of the disorder, confirm the relationship between childhood trauma and adverse features of the disorder and suggest that such events have influence on some somatic conditions in adulthood (Jaworska-Andryszewska and Rybakowski 2018).

\section{Genetic and epigenetic factors in BD pathogenesis}

The consequences of psychosocial stress, including traumatic events during childhood, may depend on genetic predisposition. Early childhood trauma may also affect the expression of genes associated with epigenetic mechanisms and in this way contribute to the development of BD. Negative experiences in the early stages of life trigger the release and modification of stress mediators and neurotransmitters in certain regions of the brain. The interaction between these mediators and the development of neurons and neural networks may lead to long-term structural and functional changes. Studies in molecular genetics indicate the possibility of interaction 
between environmental (stress) factors and polymorphism of a number of genes, which may be significant in the development and course of BD. In addition, negative childhood experiences affect DNA methylation as they constitute a type of molecular memory, which modifies brain function over the following decades.

It has been shown that there are several genes that may interact with childhood trauma, causing clinical disorders in adulthood. The most important genes of this kind are the serotonin transporter gene (5-HTT) and the FK506-binding protein gene (FKBP5), which also play an important role in the pathogenesis of affective disorders. Serotonin transporter gene promoter polymorphism (5-HTTLPR) is functional and its alleles indicate either higher ("l," "long" allele) or lower ("s," "short" allele) activity of the transporter. The study by Caspi et al. (2003) found that there is a correlation between the polymorphism of this gene and depression that develops in connection to negative life events, which was significant in the case of the " $\mathrm{s}$ " allele. Meta-analysis conducted by Karg et al. (2011) showed that having the "s" allele of 5-HTTLPR gene polymorphism is associated with a higher risk of depression developed under stress. In turn, increased expression of FKBP5 gene enhances the negative feedback of the hypothalamic-pituitary-adrenal axis (HPA), leading to the activation of the system after exposure to stress. This can be a risk factor for stress-related mental disorders, such as affective disorders (Binder 2009). It was found that carriers of a haplotype of four variants of this gene, known as CATT carriers, have a higher risk of developing mental disorders, including affective disorders in adulthood, after experiencing early childhood trauma (Binder et al. 2004).

Other genes associated with the stress axis (HPA) are the corticotropin-releasing hormone receptor 1, CRHR1 and mineralocorticoid receptor gene $M R$. In relation to both of them, a link was found between the occurrence of affective disorders in adulthood and negative events in childhood (Heim et al. 2009, Kranzler et al. 2011, Vinkers et al. 2015).

Oliveira et al. (2015) demonstrated a link between the immune system toll-like receptor 2 gene TLR2 polymorphism and earlier onset of BD resulting from sexual abuse in childhood. The relationship between early childhood trauma and bipolar disorder in adulthood was also demonstrated in relation to immune system genes, such as the interleukin 6 gene and the C-reactive protein gene (Cohen-Woods et al. 2018). Other genes that are significant in the formation of BD resulting from early childhood trauma include catechol-O-methyltransferase (COMT) and brain-derived neurotrophic factor (BDNF) (Aas et al. 2014, Ramsay et al. 2013).

Epigenetic mechanisms modify gene expression without causing changes in the DNA sequence; yet, most of the studies in this area have focused on the possibility of abnormal DNA methylation. Early development is a particularly sensitive period in relation to the possibility of epigenetic genome modification (Heim and Binder 2012). It was shown that the extensiveness of DNA methylation of the FKBP5 gene is most visible in early life and trauma in children may cause permanent epigenetic changes (Klenger and Binder 2012). Suderman et al. (2014) showed that early childhood trauma caused an increase in DNA methylation in adults in many parts of the genome. Yang et al. (2014) studied the differences in DNA methylation of the whole genome between 96 children suffering from trauma and a control group of 96 children, similar in relation to gender and age. It was found that children who experienced trauma had higher DNA methylation as compared to children in the control group.

Lutz et al. (2015) reviewed human studies indicating that DNA methylation is significant for the neurobiological consequences of childhood trauma throughout life. DNA methylation may enhance dysfunctional behavioural patterns and increase the risk of psychopathologies. They put forward the hypothesis that epigenetic mechanisms, in particular DNA methylation, form a type of molecular memory that can affect brain function in the long term.

\section{BD pharmacotherapy in the context of early childhood trauma}

Negative experiences during childhood may be associated with a poorer treatment response (Agnew-Blais and Danese 2016, Binder 2017). It is hence advisable in the case of patients with affective disorders to conduct a detailed interview taking into account negative experiences in childhood. As it was found that in the group of patients who experienced negative events in childhood, the disorder onset takes place earlier, the course of the disorder is more severe, there is an increased number of suicide attempts, the treatment response is diminished and symptoms of anxiety disorders co-occur, the aforementioned interview should in particular concern patients whose disorder has the above features.

Quilty et al. (2016) conducted a study aimed at investigating whether the affinity of antidepressants to the serotonin transporter is relevant to their efficacy in people who have experienced early childhood trauma. The study involved 52 depression outpatients who were treated for 26 weeks with antidepressants with high and low affinity to the serotonin transporter. The study confirmed the link between traumatic experiences in childhood and the response to treatment. It was found that in patients who experienced negative events in childhood, the severity of depressive symptoms after the completion of the treatment was higher in the case of the treatment based on antidepressants with low affinity to the serotonin transporter. The study suggests that, in addition to increasing biological susceptibility to depression, 
long-term exposure to stress during childhood may influence the results of pharmacological treatment. This was the first study that directly examined treatment results of patients with a history of early childhood trauma. Its results show that patients who experienced negative events in childhood may require treatment with higher serotonin transporter affinity antidepressants than those without such experiences.

Early childhood trauma may be a factor that prognoses difficult treatment of affective disorders. Williams et al. (2016) conducted a study that focused on the relationship between the experience of early childhood trauma and the effectiveness of antidepressants in severe depressive episodes. It was shown that traumatic experiences that occurred at the age of over 7 years brought about worse treatment results after eight weeks of treatment with antidepressants such as escitalopram, sertraline and venlafaxine, whereas negative experiences in children between 4 and 7 years of age were associated with worse results of sertraline treatment.

Conus et al. (2010) evaluated the occurrence of negative events in childhood in 118 patients with bipolar I disorder in the treatment of the first episode of psychotic mania. Individuals who had these kinds of experiences demonstrated worse functioning before the disorder and discontinued treatment more frequently. In such individuals, the authors recommend specific psychotherapeutic interventions in order to improve their compliance with the principles of treatment.

Traumatic experiences in childhood in BD patients may be related to resistance to treatment with mood-stabilisers. Cakir et al. (2015) examined 135 bipolar I disorder patients for early childhood trauma. They did not find any associations between the occurrence of negative events in childhood and the results of long-term use of lithium, whereas response to lithium proved to be lower in the case of post-traumatic stress disorder symptoms. In patients who had a poorer response to treatment with anticonvulsants, the results on the scale of emotional violence were higher. On the other hand, a study of $148 \mathrm{BP}$ patients conducted by Etain et al. (2017) showed that negative experiences in childhood are related to the response to lithium treatment. Patients who indicated at least two types of abuse in the interview (emotional, physical or sexual) were five times more likely to be in the 'non-responders' group when compared to patients who did not report such abuse. Poorer results of a long-term treatment with lithium were associated most strongly with higher levels of physical violence.

\section{Psychotherapy of bipolar disorder in the context of early childhood trauma}

The experience of early childhood trauma is significant for psychotherapeutic interventions in BD. Such interventions should be preceded by a detailed history of possible negative experiences during childhood. Conducting such an interview should be mandatory in the case of severely affected patients as they are more likely to have experienced trauma in childhood.

A pioneering study in this respect was carried out by Nemeroff et al. (2005). It included 681 patients with chronic depressive disorders treated with nefazodone, cognitive-behavioural therapy or a combination of these. It was found that the antidepressants by itself and psychotherapy by itself were equally less effective than a combination treatment. However, in patients with a history of early childhood trauma, such as loss of parents at an early age, physical abuse, sexual abuse or neglect, psychotherapy alone proved to be more effective than antidepressant pharmacotherapy. In patients with these types of experiences, the combination of psychotherapy and pharmacotherapy was only slightly better than psychotherapy by itself. The authors conclude that psychotherapy may be an important component of the treatment of patients with chronic severe depression who experienced childhood trauma.

In patients with childhood trauma, psychotherapy can have a biological effect. Perroud et al. (2013) examined the impact of psychotherapy on BDNF methylation. Prior to treatment, patients with borderline personality disorder (BPD) had a higher level of BDNF methylation in comparison to the control group. There was also a correlation between the frequency of negative experiences in childhood and BDNF methylation. BDNF methylation level was reassessed after 4 weeks of intensive dialectical behaviour therapy and it was found that after the four weeks of therapy, BDNF methylation level decreased. This indicates the influence of psychotherapy on epigenetic mechanisms.

The most important supporting method for pharmacological treatment of BD is psychoeducation conducted individually or during group meetings. Psychoeducation of patients with $\mathrm{BD}$ consists in presenting the biological model of the disorder and showing the patient the possibilities offered by a properly conducted pharmacotherapy. In addition to enhancing patient cooperation in relation to medication administration, psychoeducation is also significant in order to improve the patients' management of the symptoms that suggest disorder relapse. Moreover, at group meetings, an exchange of information between patients takes place, which results in overall improvement in well-being and reduction in the stigmatisation associated with the disorder. One of the best psychoeducation protocols has been developed by a university BD treatment centre in Barcelona under the supervision of Eduardo Vieta and Francesco Colom. The programme involves groups of 6 to $12 \mathrm{BD}$ patients in euthymia and includes 21 sessions focused on discussing different aspects of the disorder. Each session lasts 90 minutes and includes a presentation of the problem and 
a discussion based on an individual experience of the disorder of each participant (Colom and Vieta 2009). Comparative studies of the group who took part in the psychoeducation sessions and the group who did not have such meetings showed that the number of relapses in the first group was two times lower both after 6 months and after 2 years of observation. This applied to manic episodes, hypomanic episodes, depressive episodes and mixed states (Vieta 2005).

A promising form of treatment for patients who experienced childhood trauma is cognitive-behavioural therapy (CBT) based on Beck's depression model. Beck described a negative cognitive triad that includes a negative perception of oneself, the surrounding reality and the future. Patients who demonstrate this type of thinking are more susceptible to depression (Beck et al. 1979). Cognitive-behavioural therapy should include elements of psychoeducation, but also focus on the patient's developmental profile and the impact of experiences on the development of the most important cognitive structures formed during childhood. Basco and Rush (2007) proposed a model that takes into account most of BD components. It consists of 20 structured therapeutic sessions. It bases on the assumption that an affective episode and the associated cognitive change have emotional and behavioural consequences. Such changes lead to deterioration of general functioning (including social functioning), which is in turn associated with increased stress, disruption of biological rhythms and intensification of affective symptoms. Through changes at the cognitive, behavioural and affective levels, cognitive-behavioural therapy may have a positive influence on the course of the disorder and provide a better way of coping with it. The therapeutic programme consists of psychoeducation focused on the disorder and the medications; it also anticipates the development of the ability to notice symptoms characteristic for the patient, improvement of compliance with doctor's recommendations and development of the ability to solve psychosocial problems.

Apart from CBT, the schema therapy developed by Jeffrey Young and his co-workers (Young et al. 2015) seems to constitute an interesting form of support, especially in the case of patients who experienced negative childhood events. The schema therapy originates from cognitive-behavioural therapy and belongs to what is known as third wave of cognitive-behavioural therapies. It integrates elements of attachment theory, Gestalt theory, object relations theory, constructivism and psychoanalytic therapy, forming a comprehensive and unifying conceptual and therapeutic model. Young points out that toxic childhood experiences are the main source of early maladaptive schemas. The dynamics of the family determines the dynamics of the whole world of the child. In situations that activate early maladaptive schemas, the patients experience their childhood pain. According to the schema therapy, personality, belief system and emotional response schemas are shaped by many experiences from our past. Thanks to them, a person learns how to appropriately satisfy basic emotional needs and how to build healthy bonds. Many events that affect normal development occur without the participation of the child. During childhood, people may experience suffering, deprivation or loss that makes it impossible for them to meet their needs as children. In such a case, maladaptive strategies of coping with a given schema are developed. However, in adult life the methods developed during childhood cease to be functional (Young et al. 2015).

The use of cognitive-behavioural therapy in the treatment of BD was recently discussed by Napierała (2017). Previous studies have demonstrated the effectiveness of this method, mainly in reducing the number of relapses, reducing the intensity of symptoms during episodes of the disorder, the duration of remission and improving psychosocial functioning. Lam et al. (2000) showed that patients who took part in CBT experienced fewer episodes of the disorder, functioned better, were able to cope with the symptoms of BD better than the control group and were more willing to cooperate in relation to medication administration. In a one year long study with a control group and an experimental group of 103 patients with $\mathrm{BD}$, fewer affective episodes, shorter duration of affective episodes and better overall psychosocial functioning of the patients were found (Lam et al. 2003). Ball et al. (2006) demonstrated the efficacy of CBT, particularly when applied immediately after pharmacotherapy and pharmacological stabilisation and identified significant benefits in the 12 months following its completion. The results of these studies suggest the usefulness of conducting so-called reminder sessions to maintain beneficial effects of CBT. A study conducted by Scott et al. (2006) on a group of 253 patients did not show significant differences (CBT group, regular treatment group) in the period before a relapse although in patients with fewer than 12 episodes CBT was associated with a much smaller number of relapses.

Psychotherapy significantly enhances the effects of pharmacological treatment of BD. Regardless of whether it is conducted in the form of a group therapy or individual therapy, patients who take part in psychotherapy do better than those who do not take part in psychotherapy. Psychotherapy accelerates recovery from depressive episodes and prevents the occurrence of new episodes of mood disorder. It also helps to improve overall functioning and quality of life. A meta-analysis conducted by Swartz et al. (2014), including 35 studies, indicates similar effectiveness of individual and group CBT in comparison to other types of therapies: psychoeducation, family therapy, interpersonal psychotherapy, social rhythm therapy and combined care. Another meta-analysis evaluating the effectiveness of CBT in the treatment of BD showed that CBT slightly reduces the frequency of relapses and reduces the severity of depression and manic symptoms. 
The effectiveness of CBT was also demonstrated in relation to relapses (after 6 months of observation), especially in the case of manic episodes (Ye et al. 2016). Taking into account 19 research papers, Chiang et al. (2017) demonstrated that CBT may reduce the tendency of disorder recurrence, improve depressive symptoms, reduce the severity of manic symptoms and improve social functioning. It was shown that the duration of therapy, i.e. therapy lasting more than 12 sessions, also had a positive effect on the reduction of manic symptoms severity and the reduction of depressive symptoms was significantly greater in the case of 90-minute sessions as compared to shorter meetings.

\section{Conclusions}

Further research on the role of negative childhood experiences in the pathogenesis of bipolar disorder should integrate psychological and biological approaches. Negative childhood experiences are very significant in the development and course of affective disorders and patients who were exposed to negative events in childhood are less responsive to treatment. Therefore, history of childhood trauma in patients suffering from affective disorders may be very significant for the selection of appropriate

\section{Wstęp}

Obecny paradygmat patogenezy chorób afektywnych proponuje model interakcji gen-środowisko, łączący predyspozycję genetyczną, regulację epigenetyczną i wpływy środowiskowe (Uher 2014, Rybakowski 2017). Choroby afektywne cechują się znaczną odziedziczalnością, która jest wyższa w chorobie afektywnej dwubiegunowej (85\%) (McGuffin i wsp. 2003) niż w zaburzeniach depresyjnych nawracających (37\%) (Sulivan, Neale i Kendler 2000). Wśród czynników środowiskowych odgrywających istotną rolę w patogenezie choroby afektywnej dwubiegunowej (CHAD) wskazuje się na znaczenie wydarzeń życiowych, szczególnie mających miejsce w okresie dzieciństwa. Dotychczasowe badania wskazują, że pacjenci z CHAD istotnie częściej niż osoby zdrowe doświadczają różnych rodzajów traumy wczesnodziecięcej. Negatywne wydarzenia życiowe w okresie dziecięcym mają związek z cięższym przebiegiem CHAD i mogą się też wiązać z gorszym efektem terapeutycznym (deCodt i wsp. 2016). Wpływ traumy wczesnodziecięcej na występowanie i przebieg choroby afektywnej dwubiegunowej związany jest zarówno z predyspozycją genetyczną, jak i z mechanizmami epigenetycznymi. treatment strategies to reduce sensitivity to stress in everyday life. In bipolar disorder, pharmacotherapy is the basis of treatment; yet, psychotherapy also plays an important role. It seems that cognitive-behavioural therapy combines the largest number of effective strategies, which has been proven both by studies and meta-analyses. The use of cognitive-behavioural therapy in the treatment of $\mathrm{BD}$ supports pharmacotherapy, reducing the severity of episodes, their duration and the risk of recurrence and improving psychosocial functioning. The schema therapy constitutes another interesting approach, which may prove to be very helpful in the treatment of patients suffering from early childhood trauma. It is necessary to further investigate the effectiveness of CBT as compared to other therapeutic interventions such as psychoeducation, family therapy or social rhythm therapy.

Future studies should also evaluate the effectiveness of strategies of stress reduction used in cognitive-behavioural therapy or interventions based on mindfulness. A thorough analysis of the interaction of genetic and environmental factors can contribute to a better understanding of the impact of negative events in childhood on the development of the disorder. Such studies should be conducted on a large group and the impact of personality factors and the age at which traumatic events occurred are also worth exploring.

W niniejszym artykule omówiono wpływ traumy wczesnodziecięcej na występowanie i przebieg CHAD, rolę czynników genetycznych i epigenetycznych w tym procesie oraz znaczenie negatywnych wydarzeń okresu dziecięcego dla postępowania farmako- i psychoterapeutycznego w tej chorobie.

\section{Trauma wczesnodziecięca a występowanie i przebieg choroby afektywnej dwubiegunowej}

Traumatyzujące przeżycia oraz inne negatywne doświadczenia w dzieciństwie uważane są za stresory powodujące neurobiologiczne zmiany ośrodkowego układu nerwowego. We współczesnej psychiatrii negatywne doświadczenia dziecięce to wydarzenia opisywane jako krytyczne, stresujące, traumatyczne lub znaczące (Kasprzak i Kiejna 2013). Wśród nich wymienia się: doświadczenia przemocy seksualnej, fizycznej i emocjonalnej, osierocenie, a także inne doświadczenia spełniające kryteria do rozpoznania zespołu stresu pourazowego. Jednocześnie wskazuje się, że nie tylko sytuacje opisywane jako trauma, ale również np. doświadczenie zaniedbania czy nadmierna dyscyplina w rodzinie pochodzenia mogą być 
stresorami mogącymi mieć związek z powstawaniem chorób psychicznych (Read i wsp. 2005).

Niekorzystne zdarzenia życiowe, szczególnie w okresie dzieciństwa, mogą znacząco zwiększać ryzyko występowania CHAD. Badania retrospektywne wykazały, że pacjenci z tą chorobą częściej niż osoby zdrowe doświadczają negatywnych zdarzeń w dzieciństwie. Badanie przeprowadzone na grupie 206 pacjentów z CHAD i 94 osób z grupy kontrolnej pokazało, że pacjenci istotnie częściej doświadczali złożonych traum w okresie dzieciństwa (63\%) niż osoby z grupy kontrolnej (33\%) (Etain i wsp. 2010). Efekt ten opisywany jest też w licznych podsumowaniach i metaanalizach (Aas i wsp. 2016, Aldinger i Schulze 2017, Daruy-Filho i wsp. 2011, Etain i wsp. 2008, Fisher i Hosang 2010, Jaworska-Andryszewska i Rybakowski 2016, Kasprzak i Kiejna 2013, Palmier-Claus i wsp. 2016).

Wydarzeniem z okresu dzieciństwa mogącym mieć znaczenie dla późniejszego występowania CHAD jest doświadczenie wczesnej utraty rodzica lub długotrwała z nim rozłąka. Stwierdzono, że zwiększa ono 2,6-krotnie ryzyko rozwinięcia się choroby (Agid i wsp. 1999). Podobne badanie zrealizowane ostatnio przez Paksarian i wsp. (2015) również pokazało, że separacja z rodzicem ma istotny związek z występowaniem CHAD.

W badaniu przeprowadzonym w naszym ośrodku porównywano grupę 52 pacjentów z CHAD i 52 zdrowe osoby z grupy kontrolnej, dobrane pod względem płci i wieku. Wykazano, że pacjenci z chorobą afektywną dwubiegunową doświadczali więcej przemocy fizycznej, emocjonalnej i seksualnej, emocjonalnego i fizycznego zaniedbania, a także częściej w dzieciństwie dotykała ich śmierć rodzicielska, porzucenie, rozwód i długotrwała separacja w porównaniu z osobami kontrolnymi (Jaworska-Andryszewska i wsp. 2016).

Negatywne doświadczenia dziecięce mogą wywierać znaczący wpływ na przebieg kliniczny CHAD. Dotyczy to zarówno całkowitej liczby negatywnych doświadczeń z dzieciństwa, jak i różnych form przemocy, które odnotowano między rodzajami negatywnych doświadczeń z dzieciństwa i różnymi aspektami choroby. Doświadczanie przemocy fizycznej w dzieciństwie wiązało się z wcześniejszym pojawieniem się choroby i opóźnieniem w prawidłowym rozpoznaniu i leczeniu, występowaniem przebiegu z szybką zmianą faz (rapid-cycling), występowaniem objawów psychotycznych, prób samobójczych, poważnymi epizodami manii i większą liczbą hospitalizacji. Pacjenci doświadczający przemocy fizycznej częściej cierpieli na zespół stresu pourazowego (Post-traumatic Sress Disorder - PTSD) i nadużywali substancji psychoaktywnych. Wykorzystywanie seksualne w dzieciństwie wiązało się z wczesnym początkiem choroby, opóźnionym leczeniem, przebiegiem z szybką zmianą faz, kolejnymi próbami samobójczymi i objawami psychotycznymi, a także z cięższymi epizodami manii, współwystępowaniem PTSD i nadużywaniem substancji psychoaktywnych (Daruy-Filho i wsp. 2011, Aas i wsp. 2016). W badaniu Etain i wsp. (2013) przemoc emocjonalna wiązała się z wcześniejszym wiekiem zachorowania, próbami samobójczymi, przebiegiem rapid-cycling, większą liczbą epizodów depresyjnych, maniakalnych i hipomaniakalnych oraz nadużywaniem marihuany. W innym badaniu doświadczenie przemocy emocjonalnej miało związek z nadużywaniem substancji psychoaktywnych i przebiegiem z szybką zmianą faz (Garno i wsp. 2005). Ponadto, zaniedbanie w dzieciństwie wiązało się z wcześniejszym wiekiem zachorowania na zaburzenie afektywne dwubiegunowe (Kessing i wsp. 2004).

Post i wsp. (2013), badając 900 pacjentów z chorobą afektywną dwubiegunową wykazali, że trauma wczesnodziecięca, zwłaszcza przemoc fizyczna, emocjonalna i seksualna, wiązała się ze współistniejącymi chorobami somatycznymi. U pacjentów doświadczających przemocy fizycznej częściej występowały alergie, zespół przewlekłego zmęczenia, nadciśnienie i niedociśnienie, a także urazy głowy. Wykorzystywanie seksualne było związane z zespołem jelita drażliwego i nadużywania emocjonalnego - z zapaleniem stawów i migreną. Wykazano również związek między ogólną traumą wczesnodziecięcą a całkowitą liczbą chorób somatycznych, takich jak alergia, zapalenie stawów, astma, zespół chronicznego zmęczenia, zaburzenia miesiączkowania, fibromialgia, uraz głowy, nadciśnienie, niedociśnienie i migrena.

Najnowsza metaanaliza na temat związku negatywnych doświadczeń z dzieciństwa z wynikami klinicznymi choroby afektywnej dwubiegunowej pokazuje, że pacjenci z ChAD, którzy mieli w okresie dzieciństwa negatywne doświadczenia, charakteryzują się wcześniejszym wiekiem wystąpienia choroby, większą liczbą i nasileniem epizodów manii i depresji, większym nasileniem psychozy, większym ryzykiem współwystępowania zespołu stresu pourazowego, zaburzeń lękowych, nadużywania alkoholu, zwiększonym ryzykiem przebiegu z szybką zmianą faz, występowaniem prób samobójczych (Agnew-Blais, Danese 2016).

W badaniu polskim, które objęło 52 pacjentów z CHAD w wieku $47 \pm 12$ lat, wykazano, że negatywne wydarzenia w dzieciństwie wywierały istotny wpływ na powstawanie i przebieg choroby oraz związane były z takimi czynnikami, jak wiek wystąpienia pierwszego epizodu choroby, wiek rozpoznania choroby, obecność objawów psychotycznych, prób samobójczych, przebieg rapid-cycling, lekooporność, współwystępowanie innych zaburzeń psychicznych (zaburzenia lękowe) oraz obecność chorób somatycznych (nadciśnienie, otyłość). Przemoc i zaniedbywanie emocjonalne wiązały się z największą liczbą niekorzystnych cech klinicznych, takich jak objawy psychotyczne, próby samobójcze, przebieg z częstymi zmianami faz i zaburzenia lękowe. Nadużywanie emocjonalne wykazywało natomiast związek z niższym ryzykiem nadciśnienia tętniczego. Wykorzystywanie 
seksualne miało wpływ na wcześniejsze wystąpienie choroby, a długotrwała rozłąka z rodzicem - na zaburzenia lękowe i otyłość. Uzyskane wyniki wskazują, że przemoc emocjonalna i zaniedbanie emocjonalne są najsilniej powiązane z gorszym przebiegiem choroby, potwierdzają związek między traumą dziecięcą a niekorzystnymi cechami przebiegu choroby oraz sugerują również wpływ tych zdarzeń na niektóre stany somatyczne w wieku dorosłym (Jaworska-Andryszewska i Rybakowski 2018).

\section{Czynniki genetyczne i epigenetyczne z patogenezie ChAD}

Konsekwencje stresu psychospołecznego, w tym traumatycznych zdarzeń w okresie dzieciństwa, mogą zależeć od podatności genetycznej. Trauma wczesnodziecięca może również wpływać na ekspresję genów związaną z mechanizmami epigenetycznymi, przyczyniając się do rozwoju CHAD. Negatywne doświadczenia we wczesnych etapach życia wywołują uwalnianie oraz modyfikację mediatorów stresu i neuroprzekaźników w pewnych obszarach mózgu. Wzajemne oddziaływanie tych mediatorów z rozwojem neuronów i sieci neuronowych może prowadzić do długotrwałych zmian strukturalnych i funkcjonalnych. Badania genetyki molekularnej wskazują na możliwość interakcji między czynnikami środowiskowymi (stresowymi) a polimorfizmem szeregu genów, co może mieć znaczenie w powstawaniu i przebiegu ChAD. Ponadto, negatywne doświadczenia dziecięce wpływają na metylację DNA, stanowiąc formę pamięci molekularnej i modyfikującą czynność mózgu przez następne dziesięciolecia.

Wykazano, że istnieje kilka genów, które mogą wchodzić w interakcje z traumą dziecięcą, powodując zaburzenia kliniczne w wieku dorosłym. Wśród nich najistotniejsze są gen transportera serotoniny (5-HTT) i gen białka wiążącego FK506 (FKBP5), które to odgrywają również ważną rolę w patogenezie chorób afektywnych. Polimorfizm promotora genu transportera serotoniny (5-HTTLPR) jest funkcjonalny, a jego allele określają albo wyższą (allel „l”, long, długi) albo niższą (allel „s”, short, krótki) aktywność transportera. Badanie Caspi i wsp. (2003) wykazało interakcję między polimorfizmem tego genu a depresją rozwijającą się pod wpływem negatywnych zdarzeń życiowych, które to zjawisko było istotne w przypadku allelu „s”. Wyniki metaanalizy, którą przeprowadzili Karg i wsp. (2011), wykazały, że posiadanie allelu „s" polimorfizmu genu 5-HTTLPR wiążą się z wyższym ryzykiem rozwoju depresji pod wpływem stresu. Większa ekspresja genu FKBP5 powoduje natomiast zwiększenie ujemnego sprzężenia zwrotnego osi podwzgórze-przysadka-nadnercza (hypothalamus-pituitary-adrenal axis - HPA), prowadząc do aktywacji tego systemu po ekspozycji na stres. Może to stanowić czynnik ryzyka zaburzeń psychicznych związanych ze stresem, takich jak choroby afektywne (Binder 2009). Stwierdzono, że u nosicieli haplotypu czterech wariantów tego genu, określanych jako nosiciele CATT, istnieje większe ryzyko rozwoju zaburzeń psychicznych, w tym chorób afektywnych w wieku dorosłym, po przebyciu traumy wczesnodziecięcej (Binder i wsp. 2004).

Innymi genami związanymi z osią stresu (HPA) są gen CRHR1 receptora kortykoliberyny (corticotropin-releasing hormone type 1 receptor) oraz gen $M R$ receptora mineralkortykoidowego. W odniesieniu do obu z nich wykazano związek między powstawaniem chorób afektywnych $\mathrm{w}$ wieku dorosłym a negatywnymi wydarzeniami okresu dzieciństwa (Heim i wsp. 2009, Kranzler i wsp. 2011, Vinkers i wsp. 2015).

Oliveira i wsp. (2015) wykazali związek między polimorfizmem genu układu odpornościowego TLR-2 (Toll-like receptor gene-2) a wcześniejszym ujawnianiem się ChAD w następstwie nadużycia seksualnego w dzieciństwie. Związek między traumą wczesnodziecięcą a chorobą afektywną w wieku dorosłym został również wykazany w odniesieniu do takich genów układu odpornościowego, jak gen interleukiny- 6 oraz gen białka C-reaktywnego (Cohen-Woods i wsp. 2018). Z innych genów mających znaczenie dla powstawania ChAD w następstwie traumy wczesnodziecięcej należy wymienić gen katechol-O-metyltransferazy (Catechol-O-methyltransferase - СОМT) oraz gen czynnika neurotrofowego pochodzenia mózgowego (Brain-derived neurotrophic factor - BDNF) (Aas i wsp. 2014, Ramsay i wsp. 2013).

Mechanizmy epigenetyczne modyfikują ekspresję genów, nie powodując zmian w sekwencji DNA, a większość badań w tym zakresie skupiła się na możliwości nieprawidłowej metylacji DNA. Wczesny rozwój stanowi szczególnie wrażliwy okres dla możliwości epigenetycznej modyfikacji genomu (Heim i Binder 2012). Wykazano, że intensywność metylacji DNA genu FKBP5 jest najbardziej widoczna we wczesnym okresie życia, a uraz u dzieci może wywoływać trwałe zmiany epigenetyczne (Klenger i Binder 2012). Suderman i wsp. (2014) wykazali, że uraz wczesnodziecięcy spowodował wzrost metylacji DNA w wielu miejscach genomu u dorosłych. Yang i wsp. (2014) badali różnice metylacji DNA całego genomu pomiędzy 96 dziećmi doświadczającymi traumy i 96 dziećmi z grupy kontrolnej, dobranymi pod względem płci i wieku. Okazało się, że dzieci doświadczające traumy miały większą metylację DNA w porównaniu $\mathrm{z}$ dziećmi z grupy kontrolnej.

Lutz i wsp. (2015) dokonali przeglądu badań na ludziach wskazujących, że metylacja DNA jest ważna dla neurobiologicznych konsekwencji traumy dziecięcej przez całe życie. Metylacja DNA może wzmacniać dysfunkcjonalne wzorce behawioralne i zwiększać ryzyko psychopatologii. Wysunęli hipotezę, że mechanizmy epigenetyczne, w szczególności metylacja DNA, tworzą postać pamięci molekularnej, która może mieć wpływ na funkcjonowanie mózgu w dłuższym okresie. 


\section{Farmakoterapia ChAD w kontekście traumy wczesnodziecięcej}

Negatywne doświadczenia w okresie dzieciństwa mogą być związane z gorszą reakcją na leczenie (Agnew-Blais i Danese 2016, Binder 2017). Wskazuje się na celowość przeprowadzania szczegółowego wywiadu uwzględniającego negatywne doświadczenia w okresie dzieciństwa u pacjentów z zaburzeniami afektywnymi. Ponieważ stwierdzono, że u pacjentów, którzy doświadczali negatywnych wydarzeń w dzieciństwie, obserwowano wcześniejszy początek choroby oraz bardziej niekorzystny jej przebieg, częstsze występowanie u nich prób samobójczych oraz gorszej reakcji na leczenie, a także współwystępowanie objawów zaburzeń lękowych, powyższy wywiad winien w szczególności dotyczyć takich pacjentów.

Badanie przeprowadzone przez Quilty i wsp. (2016) miało na celu zbadanie, czy powinowactwo leków przeciwdepresyjnych do transportera serotoniny ma znaczenie dla ich skuteczności u osób, które doświadczyły traumy wczesnodziecięcej. W badaniu wzięło udział 52 pacjentów ambulatoryjnych chorych na depresję, którzy przez 26 tygodni byli leczeni za pomocą leków przeciwdepresyjnych o wysokim i małym powinowactwie do transportera serotoniny. Badanie potwierdziło związek pomiędzy traumatycznymi doświadczeniami w dzieciństwie a reakcją na leczenie. Okazało się, że u osób, które doświadczały w dzieciństwie negatywnych wydarzeń, nasilenie objawów depresyjnych po zakończeniu leczenia było wyższe w przypadku zastosowania leków przeciwdepresyjnych o słabym powinowactwie do transportera serotoniny. Badanie sugeruje, że długotrwałe narażenie na stres w okresie dzieciństwa może mieć związek, oprócz biologicznej podatności na depresję, na wyniki leczenia farmakologicznego. Było to pierwsze badanie, które bezpośrednio badało wyniki leczenia pacjentów $\mathrm{z}$ historią traumy wczesnodziecięcej. Jego wyniki wskazują, że pacjenci, którzy doświadczali w dzieciństwie negatywnych wydarzeń, mogą wymagać leczenia za pomocą leków przeciwdepresyjnych z wyższym powinowactwem do transportera serotoniny w porównaniu $\mathrm{z}$ osobami bez takiej historii.

Trauma wczesnodziecięca może być czynnikiem prognostycznym utrudnionego leczenia chorób afektywnych. Badanie przeprowadzone przez Williamsa i wsp. (2016) skupiało się na zależności między doświadczeniem traumy wczesnodziecięcej a skutecznością leków przeciwdepresyjnych w epizodzie ciężkiej depresji. Wykazano, że traumatyczne doświadczenia występujące w okresie powyżej 7. roku życia, powodowały gorsze wyniki leczenia po ośmiotygodniowym stosowaniu leków przeciwdepresyjnych, takich jak escitalopram, sertralina i wenlafaksyna. Negatywne doświadczenia dziecięce występujące między 4. a 7. rokiem życia wiązały się natomiast z gorszym wynikiem leczenia sertraliną.
Conus i wsp. (2010) oceniali występowanie negatywnych wydarzeń w wieku dziecięcym u 118 pacjentów z ChAD typu I leczonych z powodu pierwszego epizodu psychotycznej manii. Osoby, u których występowały takie wydarzenia, wykazywały gorsze funkcjonowanie przedchorobowe i częściej przerywały leczenie. U takich osób autorzy zalecają specyficzne interwencje psychoterapeutyczne w celu poprawy stosowania się ich do zasad leczenia.

Traumatyczne doświadczenia w dzieciństwie u pacjentów z ChAD mogą mieć związek z opornością na stosowanie leków normotymicznych. Cakir i wsp. (2015) badali 135 pacjentów z ChAD typu I pod kątem występowania traumy wczesnodziecięcej. Nie stwierdzili związku między występowaniem negatywnych wydarzeń w dzieciństwie a wynikami długotrwałego stosowania litu, natomiast gorszy efekt działania litu miał miejsce w przypadku występowania objawów zespołu stresu pourazowego. Wyniki na skali przemocy emocjonalnej były wyższe u osób, które gorzej reagowały na leczenie lekami przeciwdrgawkowymi. Badanie, które przeprowadzili Etain i wsp. (2017) obejmujące 148 pacjentów z ChAD wykazało, że negatywne doświadczenia w dzieciństwie mają związek z reakcją na leczenie litem. Pacjenci mający w wywiadzie, co najmniej dwa rodzaje nadużyć (emocjonalne, fizyczne lub seksualne) mieli pięciokrotnie wyższe ryzyko znalezienia się w grupie non-responders w porównaniu z pacjentami, którzy nie podawali takich nadużyć. Z gorszymi wynikami długotrwałego stosowania litu najsilniej związany był wyższy poziom przemocy fizycznej.

\section{Psychoterapia choroby afektywnej dwubiegunowej w kontekście traumy wczesnodziecięcej}

Doświadczenie traumy wczesnodziecięcej jest istotne dla podejmowanych interwencji psychoterapeutycznych w ChAD. Takie interwencje powinny być poprzedzone szczegółowym wywiadem uwzględniającym możliwe negatywne doświadczenia w okresie dzieciństwa, a wywiad taki winien być obowiązkowy u pacjentów wykazujących ciężki przebieg choroby, ponieważ taki dotyczy on częściej pacjentów z przebytą w dzieciństwie traumą.

Pionierskie w tym względzie było badanie, które wykonali Nemeroff i wsp. (2005), do którego włączono 681 pacjentów z przewlekłymi postaciami depresji, leczonych lekiem przeciwdepresyjnym nefazodonem, psychoterapią poznawczo-behawioralną lub ich kombinacją. Stwierdzono natomiast, że same leki przeciwdepresyjne i sama psychoterapia były równie znacznie mniej skuteczne niż leczenie skojarzone. Jednak wśród pacjentów, u których w przeszłości występowały urazy wczesnodziecięce, takie jak utrata rodziców we wczesnym wieku, nadużywanie fizyczne, seksualne lub zaniedbanie, sama psychoterapia przewyższała skutecznością farmakoterapię przeciwdepresyjną. U tych pacjentów połączenie 
psychoterapii i farmakoterapii było tylko nieznacznie lepsze niż sama psychoterapia. Autorzy konkludują, że psychoterapia może być istotnym elementem w leczeniu pacjentów z przewlekłymi postaciami ciężkiej depresji i doświadczeniem traumy w dzieciństwie.

U pacjentów z traumą dziecięcą psychoterapia może wywierać działanie biologiczne. Perroud i wsp. (2013) zbadali wpływ psychoterapii na metylację BDNF. Przed leczeniem pacjenci z zaburzeniem osobowości typu borderline (BPD) mieli wyższy poziom metylacji BDNF w porównaniu z grupą kontrolną. Stwierdzono również korelację pomiędzy częstością występowania negatywnych doświadczeń w dzieciństwie a metylacją BDNF. Poziom metylacji BDNF został ponownie oceniony po 4 tygodniach stosowania intensywnej dialektycznej terapii behawioralnej i okazało się, że po tym czasie zmniejszył się poziom metylacji BDNF, co wskazuje na działanie psychoterapii na mechanizmy epigenetyczne.

Najważniejszą metodą, wspomagającą leczenie farmakologiczne ChAD, jest psychoedukacja prowadzona w sposób indywidualny lub podczas spotkań grupowych. Psychoedukacja pacjentów z ChAD polega między innymi na odniesieniu się do modelu biologicznego choroby i pokazaniu pacjentowi możliwości, jakie daje właściwie prowadzona farmakoterapia. Oprócz poprawy w zakresie współpracy pacjenta przy przyjmowaniu leków, ważnym zadaniem tej metody jest również uzyskanie przez pacjenta poprawy w zakresie radzenia sobie $\mathrm{z}$ objawami zwiastującymi nawrót choroby. Na spotkaniach grupowych następuje również wymiana informacji między pacjentami, co powoduje ogólne polepszenie samopoczucia oraz zmniejszenie stygmatyzacji związanej z chorobą. Jeden z najlepszych protokołów psychoedukacyjnych został opracowany przez uniwersytecki ośrodek leczenia ChAD w Barcelonie, pod kierownictwem Eduarda Viety i Francesca Coloma. Program zakłada udział 6-12-osobowych grup pacjentów z ChAD będących w okresie eutymii i obejmuje 21 sesji, na których omawia się różne aspekty choroby. Każda sesja trwa 90 minut, podczas których odbywa się prezentacja problemu oraz dyskusja, oparta na indywidualnym doświadczeniu choroby każdego z uczestników (Colom i Vieta 2009). Badania porównawcze grupy, u której stosowano psychoedukację, z grupą bez psychoedukacji, wykazało, że w grupie pierwszej liczba nawrotów choroby była dwukrotnie niższa zarówno po 6 miesiącach, jak i po 2 latach obserwacji i dotyczyło to w równym stopniu epizodów manii, hipomanii, depresji, a także stanów mieszanych (Vieta 2005).

Obiecującą formą leczenia pacjentów przeżywających traumy z dzieciństwa jest psychoterapia poznawczo-behawioralna (cognitive-behavioral therapy - CBT) oparta na modelu depresji Becka. Beck opisał negatywną triadę poznawczą obejmującą negatywne postrzeganie siebie, otaczającej rzeczywistości i przyszłości. Pacjenci prezentujący taki typ myślenia są bardziej podatni na powstanie depresji (Beck i wsp. 1979). Terapia poznawczo-behawioralna powinna zawierać element psychoedukacji, ale także skupiać się na profilu rozwojowym pacjenta i wpływie doświadczeń na rozwój najważniejszych struktur poznawczych powstałych w okresie dzieciństwa. Model, który uwzględnia większość elementów ChAD, zaproponowali Basco i Rush (2007). Składa się on z 20 ustrukturalizowanych sesji terapeutycznych i zakłada, że epizod afektywny i związana z nim zmiana poznawcza powodują konsekwencje w zakresie emocji oraz zachowania. Zmiany te prowadzą do pogorszenia ogólnego funkcjonowania (w tym społecznego), co z kolei jest związane z nasileniem stresu, zaburzeniem rytmów biologicznych i ma wpływ na zaostrzenie objawów afektywnych. Psychoterapia poznawczo-behawioralna przez zmiany na poziomie poznawczym, behawioralnym i afektywnym może korzystnie wpływać na przebieg choroby i lepszy sposób radzenia sobie z nią. Program terapeutyczny składa się z psychoedukacji dotyczącej choroby, stosowanych leków; zakłada również nabycie umiejętności w zakresie obserwacji objawów charakterystycznych dla pacjenta, wypełniania zaleceń lekarskich i rozwój umiejętności rozwiązywania problemów psychospołecznych.

Oprócz CBT, interesującą formą pomocy, szczególnie pacjentom z doświadczeniami negatywnych wydarzeń w okresie dzieciństwa, wydaje się terapia schematów, opracowana przez Jeffreya Younga i wsp. (2015). Terapia schematów wywodzi się z terapii poznawczo-behawioralnej i należy do tak zwanej III fali terapii poznawczo-behawioralnych, integruje również elementy teorii przywiązania, Gestalt, relacji z obiektem, konstruktywizmu oraz terapii psychoanalitycznej, tworząc wyczerpujący i unifikujący model pojęciowy i terapeutyczny. Young zwraca uwagę, że toksyczne doświadczenia z dzieciństwa są głównym źródłem wczesnych nieadaptacyjnych schematów. Dynamika rodziny stanowi o dynamice całego świata dziecka. Kiedy pacjenci znajdują się w sytuacjach, które aktywują wczesne nieadaptacyjne schematy, przeżywają dramat z dzieciństwa. W myśl terapii schematów, osobowość, system przekonań czy wzorce reagowania emocjonalnego kształtuje wiele doświadczeń naszej przeszłości. Dzięki nim człowiek uczy się, w jaki sposób adekwatnie zaspokajać podstawowe potrzeby emocjonalne, i jak budować bezpieczne więzi. Wiele wydarzeń, które mają wpływ na prawidłowy rozwój pozostaje najczęściej bez udziału dziecka. Ludzie w okresie dzieciństwa doświadczają też cierpienia, deprywacji lub straty, która uniemożliwia im zaspokajanie potrzeb jako dzieci. Wówczas dochodzi do rozwoju nieadaptacyjnych strategii radzenia sobie z danym schematem i w życiu dorosłym metody wypracowane w okresie dzieciństwa przestają być funkcjonalne (Young i wsp. 2015).

Zastosowanie psychoterapii behawioralno-poznawczej w leczeniu ChAD omówiła ostatnio Napierała (2017). Dotychczasowe badania wykazały skuteczność tej metody, głównie w zakresie zmniejszenia liczby nawrotów 
choroby, zmniejszenia nasilenia objawów w trakcie epizodów choroby, czasu trwania remisji i poprawy funkcjonowania psychospołecznego. Lam i wsp. (2000) wykazali, że osoby korzystające z CBT doświadczały mniejszej liczby epizodów choroby, lepiej funkcjonowały, potrafiły też lepiej sobie radzić z objawami ChAD w porównaniu z grupą kontrolną oraz chętniej współpracowały w kwestii przyjmowania leków. W rocznym badaniu z grupą kontrolną i grupą eksperymentalną składającą się z 103 pacjentów z ChAD stwierdzono mniejszą liczbę epizodów afektywnych, krótszy czas ich trwania oraz lepsze ogólne funkcjonowanie psychospołeczne pacjentów (Lam i wsp. 2003). Ball i wsp. (2006) wykazali skuteczność CBT, szczególnie natychmiast po leczeniu i ustabilizowaniu farmakologicznym i wskazali istotne korzyści w kolejnych 12 miesiącach po zakończeniu. Wyniki tych badań sugerują zasadność prowadzenia tak zwanych sesji przypominających w celu utrzymania korzystnych efektów CBT. Badanie przeprowadzone przez Scott i wsp. (2006) na grupie 253 pacjentów nie wykazało znaczących różnic (grupa CBT, grupa z normalnym leczeniem) w czasie do wystąpienia nawrotu, chociaż wśród pacjentów z liczbą mniejszą niż 12 epizodów, CBT była związana ze znacznie mniejszą liczbą nawrotów.

Psychoterapia istotnie polepsza efekty leczenia farmakologicznego ChAD. Niezależnie od tego, czy jest prowadzona w formie grupowej czy indywidualnej, ci, którzy otrzymują psychoterapię, radzą sobie lepiej niż pozostali. Psychoterapia przyspiesza powrót do zdrowia po epizodach depresyjnych i zapobiega nowym epizodom zaburzonego nastroju. Pomaga również poprawić funkcjonowanie i jakość życia. Metaanaliza Swartza i wsp. (2014), uwzględniająca 35 badań wskazuje na podobną skuteczność indywidualnych oraz grupowych oddziaływań CBT w porównaniu z pozostałymi oddziaływaniami terapeutycznymi: psychoedukacją, terapią rodzin, psychoterapią interpersonalną i rytmów społecznych oraz opieki łączonej. Kolejna metaanaliza, oceniająca skuteczność CBT w leczeniu ChAD wykazała, że CBT nieznacznie zmniejsza częstość nawrotów choroby oraz zmniejsza nasilenie depresji, w tym również objawów manii. Wykazano również skuteczność CBT w przypadku nawrotów choroby (po 6 miesiącach obserwacji), zwłaszcza w zakresie epizodów manii (Ye i wsp. 2016). Chiang i wsp. (2017), uwzględniając 19 prac badawczych, wykazali, że CBT może obniżyć nawrotowość choroby, poprawić objawy depresyjne, zmniejszyć nasilenie manii oraz poprawić funkcjonowanie społeczne. Wykazano,

Conflict of interest and financial support was not declared. / Nie zgłoszono konfliktu interesów oraz dofinansowania.

The work described in this article has been carried out in accordance with The Code of Ethics of the World Medical Association (Declaration of Helsinki) for experiments involving że czas trwania terapii, to jest terapii trwającej powyżej 12 sesji, wpływała także pozytywnie na zmniejszenie nasilenia manii, a zmniejszenie objawów depresji było istotnie większe, jeżeli sesje terapii trwały 90 minut, w porównaniu z krótszymi sesjami.

\section{Podsumowanie}

Dalsze badania nad rolą negatywnych doświadczeń dziecięcych w patogenezie choroby afektywnej dwubiegunowej powinny integrować podejście psychologiczne i biologiczne. Negatywne doświadczenia dziecięce są bardzo ważne dla powstawania i przebiegu chorób afektywnych, a pacjenci, którzy byli w dzieciństwie narażeni na negatywne wydarzenia, gorzej reagują na leczenie. Historia urazów dziecięcych u pacjentów cierpiących z powodu zaburzeń afektywnych może być bardzo ważna do dostosowania odpowiednich strategii leczenia, mających na celu zmniejszenie wrażliwości na stres w codziennym życiu. W chorobie afektywnej dwubiegunowej farmakoterapia jest podstawą leczenia, ale istotną rolę odgrywa też psychoterapia. Wydaje się, że psychoterapia poznawczo-behawioralna łączy w sobie najwięcej skutecznych oddziaływań, co zostało udowodnione zarówno w pracach badawczych, jak i w tych o charakterze metaanaliz. Zastosowanie terapii poznawczo-behawioralnej w leczeniu ChAD wspomaga terapię farmakologiczną, obniżając intensywność epizodów, czas ich trwania, zmniejszając ryzyko wystąpienia nawrotu oraz poprawiając funkcjonowanie psychospołeczne. Interesującym podejściem jest również terapia schematów, która może okazać się niezwykle pomocna w leczeniu osób z doświadczeniem traumy wczesnodziecięcej. Konieczne jest dalsze badanie skuteczności CBT w porównaniu z innymi interwencjami terapeutycznymi, takimi jak psychoedukacja, terapia rodzin czy rytmów dobowych.

Przyszłe badania powinny oceniać również skuteczność np. strategii zmniejszania stresu stosowanych w terapii poznawczo-behawioralnej lub interwencji opartych na uważności. Do lepszego zrozumienia wpływu negatywnych wydarzeń w okresie dzieciństwa na rozwój choroby może się przyczynić wnikliwa analiza interakcji czynników genetycznych i środowiskowych. Badania takie powinny być prowadzone na dużej populacji osób, przy czym warto również rozważyć wpływ czynników osobowościowych oraz uwzględniać wiek, kiedy dochodziło do traumatycznych wydarzeń. humans, EU Directive 2010/63/EU for animal experiments, and Uniform Requirements for manuscripts submitted to biomedical journals. / Treści przedstawione $w$ artykule są zgodne z zasadami Deklaracji Helsińskiej, dyrektywami EU oraz ujednoliconymi wymaganiami dla czasopism biomedycznych. 
Authors' contributions / Wkład autorów: All the authors made a sizeable contribution to the preparation of this work / Wszyscy autorzy wnieśli zasadniczy wkład w przygotowanie pracy.

\section{References / Piśmiennictwo}

1. Aas M, Henry C, Andreassen OA, Bellivier F, Melle I, Etain B. The role of childhood trauma in bipolar disorder. Int J Bipolar Disord 2016; 4: 2.

2. Aas M, Haukvik UK, Djurovic S, Tesli M, Athanasiu L, Bjella $\mathrm{T}$ et al. Interplay between childhood trauma and BDNF val66 met variants on blood BDNF mRNA levels and on hippocampus subfields volumes in schizophrenia spectrum and bipolar disorders. J Psychiatr Res 2014; 59: 14-21.

3. Agid O, Shapira B, Zislin J, Ritsner M, Hanin B, Murad H et al. Environment and vulnerability to major psychiatric illness: a case control study of early parental loss in major depression, bipolar disorders and schizophrenia. Mol Psychiatry 1999; 4: 163-172.

4. Agnew-Blais J, Danese A. Childhood maltreatment and unfavourable clinical outcomes in bipolar disorder: a systematic review and meta-analysis. Lancet Psychiatry 2016; 3: 342-349.

5. Aldinger F, Schulze TG. Enviromental factors, life events, and trauma in the course of bipolar disorder. Psychiatry Clini Neurosci 2017; 71: 6-17.

6. Ball JR, Mitchell PB, Corry JC, Skillecom A, Smith M, Malhi GS. A randomized controlled trial of cognitive therapy for bipolar disorder: focus on long-term change. J Clin Psychiatry 2006; 67: 277-286.

7. Basco MR, Rush AJ. Zaburzenia afektywne-dwubiegunowe. Terapia poznawczo-behawioralna. WUJ, Kraków, 2007.

8. Beck AT, Rush AJ, Shaw BF, Emery G. Cognitive therapy of depression. Guilford, New York, 1979.

9. Binder EB, Salyakina D, Lichtner P, Wochnik GM, Ising $M$, Putz B et al. Polymorphisms in FKBP5 are associated with increased recurrence of depressive episodes and rapid response to antidepressant treatment. Nat Genet 2004; 36: 1319-1325.

10. Cakir S, Tasdelen Durak R, Ozyildirim, Ince E, Sar V. Childhood trauma and treatment outcome in bipolar disorder. J Trauma Dissociation 2015; 17: 397-409.

11. Caspi A, McClay J, Moffitt TE, Mill J, Martin J, Craig IW et al. Role of genotype in the cycle of violence in maltreated children. Science 2002; 297(5582): 851-854.

12. Chiang KJ, Tsai JC, Liu D, Lin CH, Chiu HL, Chou KR. Efficacy of cognitive behavioral therapy in patients with bipolar disorder: A meta-analysis of randomized controlled trials. PLoS One 2017; 12: e0176849.

13. Cohen-Woods S, Fisher HL, Ahmetspahic D, Douroudis K, Stacey D, Hosang GM et al. Interaction between childhood maltreatment on immunogenetic risk in depression: Discovery and replication in clinical case-control samples. Brain Behav Immun 2018; 67: 203-210.

14. Colom F, Vieta E. Podręcznik psychoedukacji w zaburzeniach afektywnych dwubiegunowych. Medipage, Warszawa, 2009.

15. Conus P, Cotton S, Schimmelmann BG, Berk M, Daglas R, McGorry PD. Pretreatment and outcome correlates of past sexual and physical trauma in 118 bipolar I disorder patients with a first episode of psychotic mania. Bipolar Disord 2010; 12: 244-252.

16. Daruy-Filho L, Brietzke E, Lafer B, Grassi-Oliveira R. Childhood maltreatment and clinical outcomes of bipolar disorder. Acta Psychiatr Scand 2011; 124: 427-434.
17. de Codt A, Monhonval P, Bongaerts X, Belkacemi I, Tecco JM. Bipolar disorder and early affective trauma. Psychiatr Danub 2016; 28 (Suppl. 1): 4-8.

18. Etain B, Aas M, Andreassen OA, Lorentzen S, Dieset I, Gard $\mathrm{S}$ et al. Childhood trauma is associated with severe clinical characteristics of bipolar disorder. J Clin Psychiatry. 2013; 74: 991-998.

19. Etain B, Lajnef M, Brichant-Petitjean C, Geoffroy PA, Henry C, Gard S et al. Childhood trauma and mixed episodes are associated with poor response to lithium in bipolar disorder. Acta Psychiatr Scand 2017; 135: 319-327.

20. Fisher H, Hosang G. Childhood maltreatment and bipolar disorder: a critical review of the evidence. Mind Brain 2010; 1: 750-785.

21. Garno J, Goldberg J, Ramirez PM, Ritzler BA. Impact of childhood abuse on the clinical course of bipolar disorder. Br J Psychiatry 2005; 186: 121-125.

22. Heim C, Binder EB. Current research trends in early life stress and depression: review of human studies on sensitive periods, gene-environment interactions, and epigenetics. Exp Neurol 2012; 233(1): 102-111.

23. Heim C, Bradley B, Mletzko TC, Deveau TC, Musselman $\mathrm{DL}$, Nemeroff CB et al. Effect of childhood trauma on adult depression and neuroendocrine function: Sex-specific moderation by CRH receptor 1 gene. Front Behav Neurosci 2009; 3: 41.

24. Jaworska-Andryszewska P, Rybakowski J. Negatywne doświadczenia dziecięce a powstawanie i przebieg choroby afektywnej dwubiegunowej. Psychiatr Pol 2016; 50: 989-1000.

25. Jaworska-Andryszewska P, Abramowicz M, Kosmala A, Klementowski K, Rybakowski J. Trauma wczesnodziecięca w chorobie afektywnej dwubiegunowej. Neuropsychiatr Neuropsychol 2016; 11(2): 39-46.

26. Jaworska-Andryszewska P, Rybakowski J. Childhood adversity and clinical features of bipolar mood disorder. Archives Psychiatry and Psychoteraphy 2018; 2: 13-19.

27. Karg K, Burmeister M, Shedden K, Sen S. The serotonin transporter promoter variant (5-HTTLPR), stress, and depression meta-analysis revisited. Arch Gen Psychiat 2011; 68(5): 444-454.

28. Kasprzak M, Kiejna A. Badania nad rolą wydarzeń życiowych w zaburzeniu afektywnym dwubiegunowym. Psychiatr Pol 2013; 47: 875-885.

29. Kessing LV, Agerbo E, Mortensen PB. Major stressful life events and other risk factors for first admission with mania. Bipolar Disord 2004; 6: 122-129.

30. Klengel T, Binder EB. Epigenetics of stress-related psychiatric disorders and gene $\mathrm{x}$ environment interactions. Neuron 2015; 86: 1343-1357.

31. Kranzler HR, Feinn R, Nelson EC, Covault J, Anton RF, Farrer $L$ et al. A CRHR1 haplotype moderates the effect of adverse childhood experiences on lifetime risk of major depressive episode in African-American women. Am J Med Genet B Neuropsychiatr Genet 2011; 156B(8); 960-968.

32. Lam DH, Bright J, Jones S, Hayward P, Schuck N, Chisholm $\mathrm{D}$ et al. Cognitive therapy for bipolar illness - A pilot study of relapse prevention. Cognitive Ther Res 2000; 24(5): 503-520.

33. Lutz PE, Almeida D, Fiori LM, Turecki G. Childhood maltreatment and stress-related psychopathology: The epigenetic memory hypothesis. Curr Pharm Des 2015; 21(11): 1413-1417.

34. Napierała M. Terapia poznawczo-behawioralna w leczeniu zaburzeń afektywnych dwubiegunowych. Neuropsychiatria i Neuropsychologia 2017; 12(3): 118-125. 
35. Nemeroff CB, Heim CM, Thase ME. Differential responses to psychotherapy versus pharmacotherapy in patients with chronic forms of major depression and childhood trauma. Proc Natl Acad Sci USA 2003; 100: 14293-14296.

36. Oliveira J, Etain B, Lajnef M, Hamdani N, Bennabi M, Benqoufa $\mathrm{D}$ et al. Combined effect of TLR2 gene polymorphism and early life stress on the age at onset of bipolar disorders. Plos one $2015 ; 10: 1-13$.

37. Paksarian D, Eaton WW, Mortensen PB, Merikangas KR, Pedersen CB. A population-based study of the risk of schizophrenia and bipolar disorder associated with parentchild separation during development. Psychol Med 2015; 45: 2825-2837.

38. Palmier-Claus J, Berry K, Bucci S, Mansell W, Varese F. Relationship between childhood adversity and bipolar affective disorder: systematic review and meta-analysis. Brit J Psych 2016; 209: 454-459.

39. Perroud N, Salzmann A, Prada P, Nicastro R, Hoeppli ME, Furrer $\mathrm{S}$ et al. Response to psychotherapy in borderline personality disorder and methylation status of the bdnf gene. Translational Psychiatry 2013; 3: 207.

40. Popiel A, Pragłowska E. Psychoterapia poznawczo-behawioralna - praktyka oparta na badaniach empirycznych. Psychiatria w Praktyce Klinicznej 2009; 2: 146-155.

41. Post R, Altshuler L, Leverich GS, Frye MA, Suppes T, McElroy SL et al. Role of childhood adversity in the development of medical co-morbidities associated with bipolar disorder. J Affect Disord 2013; 147(1-3): 288-294.

42. Quilty L, Marshe V, Lobo D, Harkness KL, Muller DJ, Bagby BM. Childhood abuse history in depression predicts better response to antidepressants with higher serotonin transporter affinity: a pilot investigation. Neuropsychobiology 2016; 29: 78-83.

43. Ramsay H, Kelleher I, Flannery P, Clarke MC, Lynch F, Harley $\mathrm{M}$ et al. Relationship between the COMT-Val158Met and BDNF-Val66Met polymorphisms, childhood trauma and psychotic experiences in an adolescent general population sample. PLoS One 2013; 8(11): e79741.

44. Read J, van Os J, Morrison AP, Ross CA. Childhood trauma, psychosis and schizophrenia: a literature review with theoretical and clinical implications. Acta Psychiatr Scand 2005; 112: 330-350.

45. Rybakowski JK. Recent advances in the understanding and management of bipolar disorder in adults. F1000Res 2017; 6: 2033.

46. Scott J, Paykel E, Morriss R, Bentall R, Kinderman B, Johnson $\mathrm{T}$ et al. Cognitive-behavioural therapy for severe and recurrent bipolar disorders: randomized controlled trial. Br J Psychiatry 2006; 188: 313-320.

47. Suderman M, Borghol N, Pappas JJ, Pinto Pereira SM, Pembrey M, Hertzman C et al. Childhood abuse is associated with methylation of multiple loci in adult DNA. BMC Med Genomics 2014; 7: 13.

48. Sullivan PF, Neale MC, Kendler KS. Genetic epidemiology of major depression: review and meta-analysis. Am J Psychiat 2000; 157(10): 1552-1562.

49. Uher R. Gene-environment interactions in severe mental illness. Front Psychiatry 2014; 5: 48.

50. Vieta E. Improving treatment adherence in bipolar disorder through psychoeducation. J Clin Psychiatry 2005; 66: 24-29.

51. Vinkers CH, Joëls M, Milaneschi Y, Gerritsen L, Kahn RS, Penninx BW et al. Mineralocorticoid receptor haplotypes sex-dependently moderate depression susceptibility following childhood maltreatment. Pychoneuroendocrinology 2015; 54: 90-102.

52. Williams LM, Debasttista C, Duchemin AM, Schatzberg AF, Nemeroff CB. Childhood trauma predicts antidepressant response in adults with major depression: data from the randomized international study to predict optimized treatment for depression. Transk Psychiatry 2016; 6: e799.

53. Yang BZ, Zhang H, Ge W, Weder N, Douglas-Palumberi H, Perepletchikova $\mathrm{F}$ et al. Child abuse and epigenetic mechanisms of disease risk. Am J Prev Med 2013; 44(2): 101-107.

54. Ye B, Jiang Z, Li X, Cao B, Cao LP, Lin Y et al. Effectivness of cognitive behavioral therapy In treating bipolar disorder: An updated meta-analysis with randomized controlled trials. Psychiatry\&Clinical Neurosciences. 2016; 70: 351-361.

55. Young J, Klosko J, Weishaar M. Terapia schematów. Przewodnik Praktyka. Gdańskie Wydawnictwo Psychologiczne, Gdańsk, 2015. 